\title{
Neo-classicism and the other Revivals in 1840 New Zealand: British Domestic Design in Indigenous Materials
}

William Cottrell, PhD candidate, Art History, School of Humanities, Canterbury University

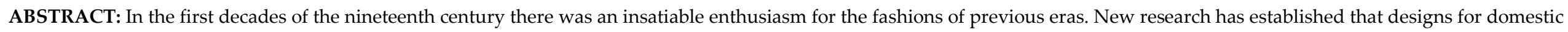

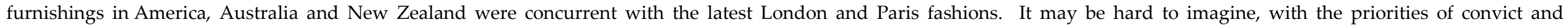
missionary life in the Australasian colonies, that influence of some of the greatest English designers was of any importance.

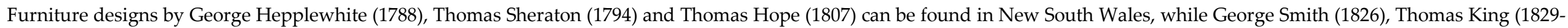

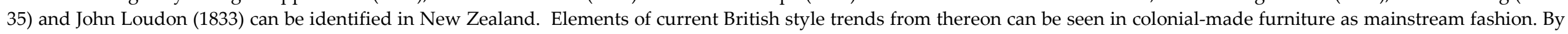

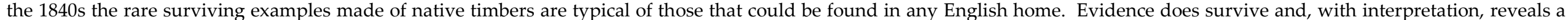
consistent influx of modern styles into the new colonies.

Very little pre-1840 architecture survives in New Zealand. Images from the first few decades of European habitation illustrate typically modest Georgian buildings. They are comparable to their Australian counterparts and stylistically inseparable from the British experience. It should be unsurprising that, as with language and culture, style invisibly travelled along with colonist luggage. Although the very remaining examples of preVictorian New Zealand architecture are insufficient to illustrate a complete genre of style, the colonial-made domestic furniture goes much further.

New research is uncovering a surprisingly broad and modern range of New Zealandmade furniture fashions in the earliest decades of European settlement. Several pitsawn kauri missionary-made sofas originating in the Bay of Islands probably form the earliest known series of objects establishing an intention to replicate British-based fashion; in that example the predominant neo-classical taste for Grecian. Although much debased, we can still interpret the scrolled ends, an undeniably Grecian form, popularly revived since the turn of the nineteenth century. They are clearly derivative of designs from the Cabinet Maker's Book of Prices issued both in England and America after 1788, notably the 1817 edition.

Once it is established that designs from as early as the 1820 s did indeed get to $\mathrm{New}$ Zealand then the discussion moves from "if" to "how often" and once alerted to the researcher's eye, clues and signature design profiles appear familiar.
English designer George Smith, a devotee of wealthy author, banker and classical antiquarian Thomas Hope, produced two formative and highly influential pattern books. His 1808 Collection of Designs drew directly from Hope's 1807 Household Furniture and Interior Decoration. These two major works cemented ancient Middle Eastern decorative taste firmly into the English home.

Two decades on, Smith's 1826 Cabinet-Makers Guide moved on to include more recent revivals. ${ }^{1}$ Egyptian, Etruscan and the

\footnotetext{
${ }^{1}$ Furniture historian Edward Joy asserts that Smith's Guide could not have been published before 1828 as some plates are dated to that year. Joy English Furniture 1800-1851 p 70. The Guide clearly states on the title page "Published by Jones and Co. Acton Place, Kingsland Road. 1826." This inconsistency would occur when additional plates were sold separately and, as was
} 
predominant Greek remained, but he took to the new fad for gothic and Louis XIV with constrained flair, well aware of his middleclass audience. This was most visible in Australia with the filter of distance and the immediacy of colonial requirement.

Smith's 1826 designs found in Australian colonial furniture, are often exact and without modification. Typically, as indicated with Sheraton, Hepplewhite or Hope, direct lineage was obscured by simplification, often for economy, or simply a fusion of designs. The latter arising through the copying of English imports while cabinetmakers or their clients might attempt to modify (expensive) outlandish designer excesses. That Smith's astute design reinterpretations were often used intact demonstrated his appeal to the colonial mind.

Many examples exist where Smith's designs have been faithfully manufactured into early Australian colonial furniture. Fahey and Simpson's Australian Furniture - Pictorial History and Dictionary 1788-1938 illustrate a broad range of such domestic objects: Grecian card and library tables, a Grecian sofa, dwarf

common practice, independently bound.

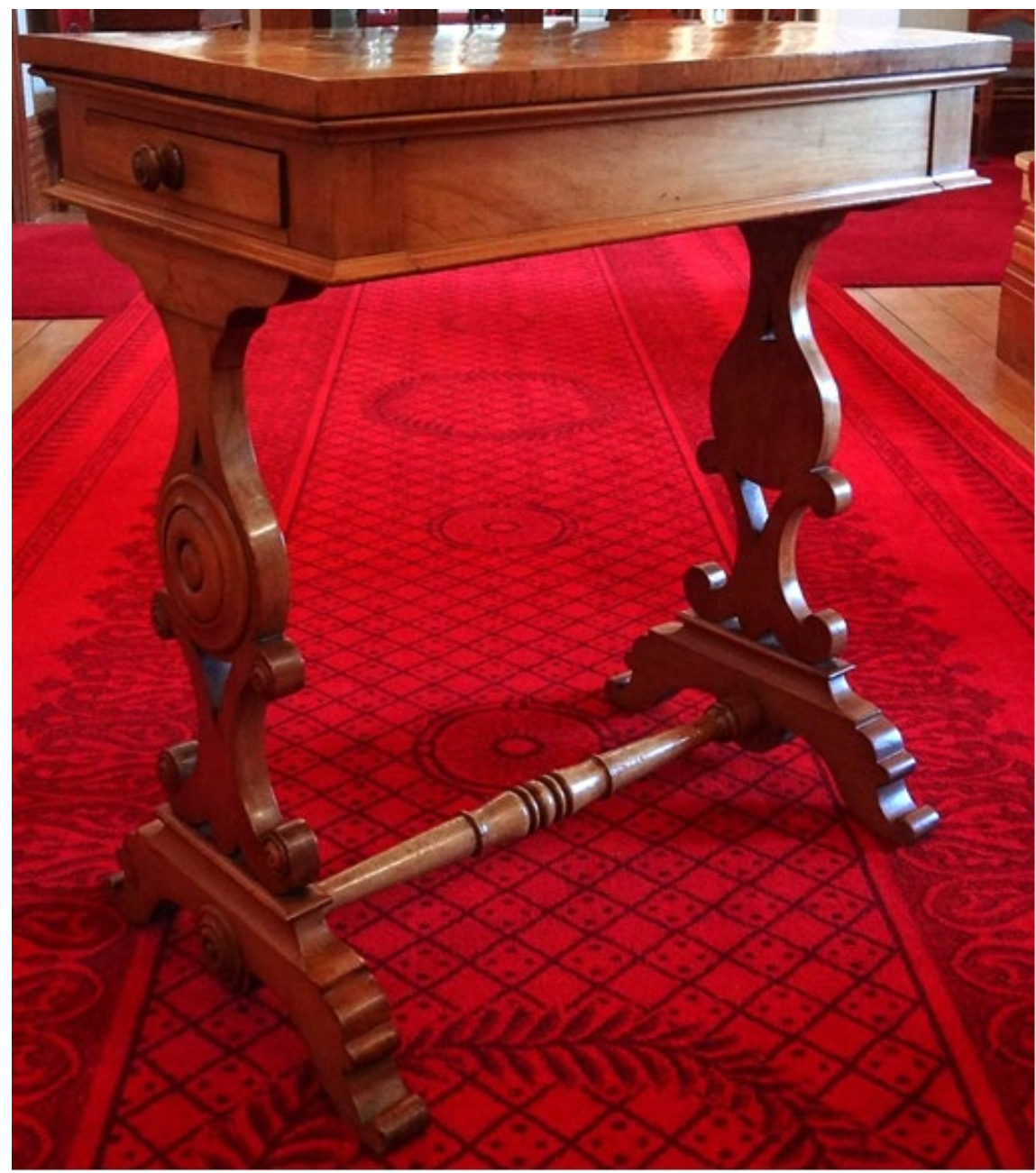

Figure 1: Rimu Table made to George Smith 1826 design

bookcase, a piano stool, and a console table. ${ }^{2}$

${ }^{2}$ Fahey \& Simpson Australian Furniture Pictorial History and Dictionary pp 383, 474, 157, 381, 413.
Remarkably, a pair of gothic bookcases by Sydney cabinetmaker Joseph Sly, made about 1845, were actually from Smith's earlier 1808 


\section{A Collection of Designs. ${ }^{3}$}

A rimu work table found and almost certainly made in Auckland is directly from Smith's 1826 Cabinet-Maker's and Upholsterer's Guide. This is the oldest identified example of New Zealand colonial-made furniture that can be attributed to an English pattern book (Figure 1). As with all period cabinet work, Smith's Guide was just that; and so there are craftsman variations but the attribution is undeniable. Most often we see this as a reduction of ornamentation, partly as beyond the natural competency of the cabinetmaker, and the work table has traded simpler turnings for more complex carved detail. Taking this lead, we can then see that Smith's designs can be seen on other colonial-made furniture from the earliest years of settlement. The pattern book provided inspiration for endless reinterpretation of design so that an object's design origins are often obscure. For example, an Australian cedar and kauri bookcase secretaire found in Auckland is strongly suggestive of Smith's thinking. The Grecian architectural form is characteristically linear with conservative embellishment and is

${ }^{3}$ Fahey \& Simpson Australian Furniture Pictorial History and Dictionary pp 166-167.

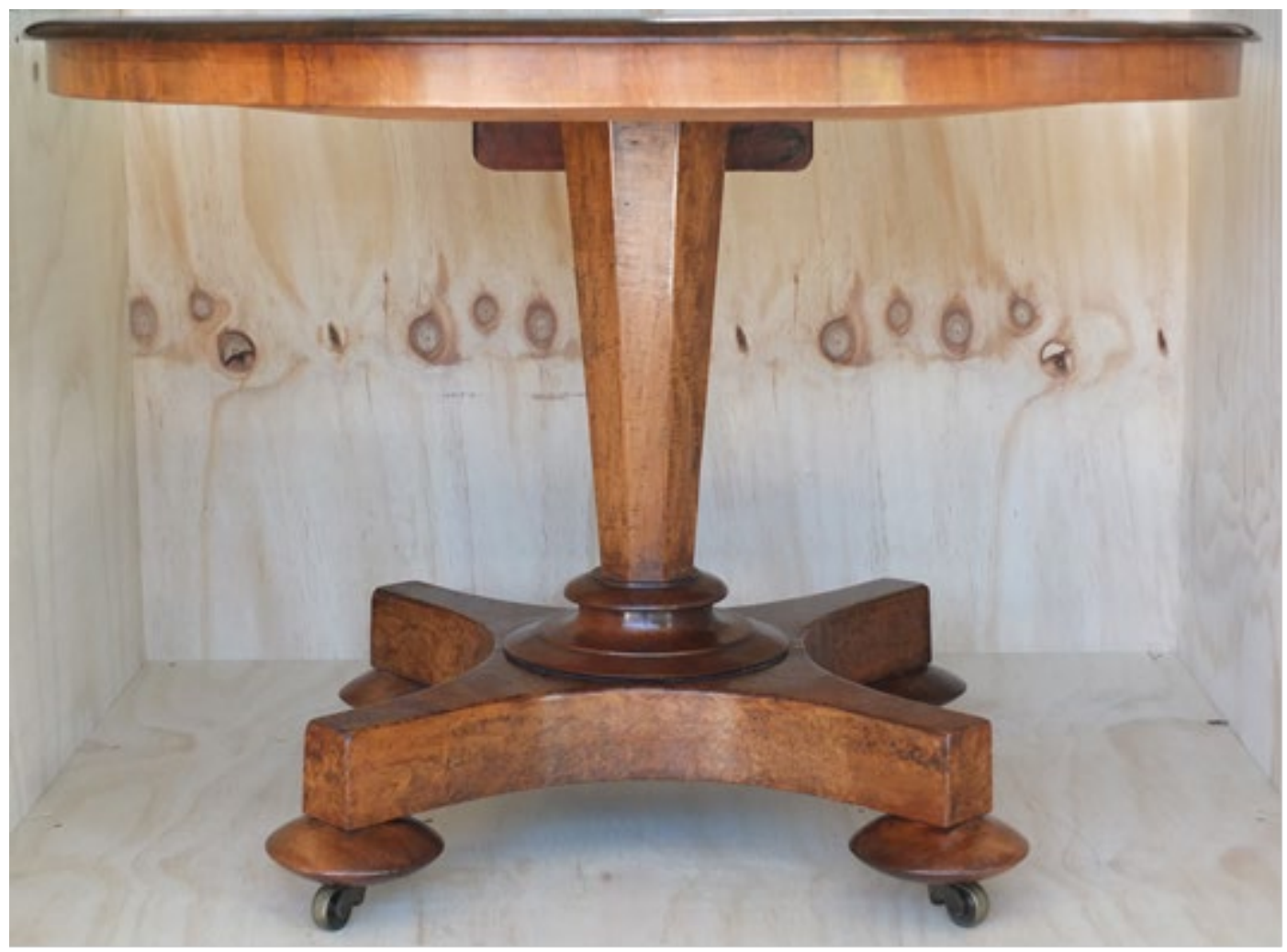

Figure 2: Josephus Hargreaves tōtara table made in Nelson to a design by Thomas King c1842

defined with little more than subtle mouldings, a block entablature and arched spandrels with roundels to the knee hole. Such was the popularity of Smith's Guide it was partly reproduced without attribution in the United States in 1833 as was his contemporary Londoner Thomas King's 1829 Modern Style of Cabinet Work Exemplified in 1840.
Thomas King, like Smith, had perfectly defined and then refined popular fashion. King's Modern Style was an instant success and, as with Smith, was still being reprinted in the 1860s, such was both men's vision and appeal. Some observers might disagree, but Smith's Guide, along with King's Modern Style did more than any other publications to influence the next half century of design. 
With minimally 28 publications attributed to King between 1823 and c1842, Modern Style (possibly) his sixth pattern book was certainly his most famous and influential. ${ }^{4}$ King's title "Modern" shifted the emphasis from scholarship to give street currency to his pared down Grecian "Style." It was expanded and revised in 1835 with Supplementary Plates of 62 new designs added in $1840^{5}$ to become the standard work of the period.

Thomas King was hugely influential and popular, simplifying Thomas Hope's formative but often didactic Grecian interpretations of "English Empire."6 For his "Touts les Louis" or "Old French" he borrowed the curvaceous scrolls, foliage and shells in

${ }^{4}$ Smith, T.G., Appendix II p xvii. Not all are known to exist and, in some cases, King refers to other his other works or advertisements mention their existence.

${ }^{5}$ Joy English Furniture 1800-1851 p 149.

${ }^{6}$ Hope had written Household Furniture and Interior Decoration in 1807. Inspired following his extensive travels through the Ottoman Empire, Syria, Egypt and Arabia after 1794 he developed a deep interest in classical architecture. Hope lived in Constantinople for a year familiarising himself with foreign cultures while voraciously collecting artworks and artefacts. His furniture designs have been described as an uninspiring mix of Egyptian and Roman motifs. That said he still did much to stimulate public interest in ancient Middle Eastern style. the "Parisian Taste" as he put it and recommended gilding, a surprisingly cheap option. Gothic was not a significant theme and only occasionally did King make mention that he had included some elements, however, after 1835, he did gradually introduce Elizabethan. ${ }^{7}$

A catalogue of an estate sale held in Sydney in 1848 included five of King's pattern books. ${ }^{8}$ Evidence of King's designs made into Australian furniture c1830-45 are commonplace demonstrating reference to Modern Style et al. as the primary source. As with most designs, many have modifications or adaptions. King intended this to be so. Fahey and Simpson illustrate no less than six card, console and side tables as well as a wardrobe, either partly or exactly, from King's Modern Style and his 1835 Cabinet Maker's Sketchbook. ${ }^{9}$

${ }^{7}$ The first indication of this was his 1835 designs for four sofas he called "Nelson seats" after the popular naval hero. Still heavily influenced by Modern Greek even with these, it would take until c1842 for him to produce Specimens of Furniture in the Elizabethan and Louis Quatorze Styles.

${ }^{8}$ Fahey \& Simpson Australian Furniture Pictorial History and Dictionary p 388

${ }^{9}$ Fahey \& Simpson Australian Furniture Pictorial History and Dictionary pp 385-386, 388, 394, 412, 445, 497.
Cabinetmaker Josephus Hargreaves arrived in Nelson aboard the "Lord Auckland" on 26th February 1842. Hargreaves brought with him his wife Jane, their nine children and the (then) most recent edition of King's Sketch Book. Although it has not survived, at least five authenticated examples of Hargreaves work do remain which show that he referred to King's (1835) designs. There were more pieces by Hargreaves that had been bequeathed by his daughter Violet to the Dominion Museum, Wellington in 1956. Unfortunately, they were destroyed with the collapse of Harley's Brewery malt house where they were stored in Nile Street East, Nelson just two years later in 1958. ${ }^{10}$

In 1997 a tōtara loo table was found in Ponsonby, Auckland (Figure 2). Part of this table's quadraform or platform base closely resembled that of a small work table which had been lost in the malt house tragedy. Hargreaves had styled his own distinctive bun foot as a discus and below that fitted highly visible all brass castors. ${ }^{11}$ The

${ }^{10}$ Northcote-Bade Colonial Furniture in New Zealand pp 70-71.

${ }^{11}$ Styles aside, these castors with the brass wheel or bowl were becoming outdated by the late 1840s to those of white porcelain. Such a visible feature would have been 
Ponsonby table was a virtual copy of two of King's 1835 designs and the Hargreaves attribution was confirmed when the initials $\mathrm{JH}$ were found after the apron was removed for restoration. ${ }^{12}$ In an extraordinary near repeat of history this important table only just escaped complete destruction with the collapse of a chimney stack during the 7.1 Richter scale earthquake in Canterbury on 4 September 2010.

Two identical tōtara arm chairs by Hargreaves have been separately located in Nelson. They compare closely to King's 1829 and 1835 design of Chairs with Inclining Backs. ${ }^{13}$ There is more confirmation of the widespread use of King's designs with yet another chair discovery in Auckland, but this time by an unidentified maker. Again, it was King's Easy Chairs with Inclined Seats (and Backs). This upholstered gentleman's armchair was an amalgamation of three plates of King's largely modified Grecian designs. Constructional details such as nail types suggest it was made in the mid 1840s, and therefore almost certainly the oldest upholstered chair so far

a clear clue as to likely date of manufacture.

${ }^{12}$ Cottrell Furniture of the New Zealand Colonial Era p 163.

${ }^{13}$ Hargreaves was known to have made six originally; one is in the Nelson Provincial Museum.

\section{identified.}

In 2000 this writer was given a box to restore that had been severely damaged by water while in the possession of a regional Northland museum. The initial water damage was further compounded by inept attempts of a staff member to repair it, particularly through the inappropriate use of modern synthetic adhesives. The marquetry box featured mānuka flowers framed by rococo scrolls to the lid with specimen gothic windows of native timbers to the sides and was made by Anton Seuffert's eldest son, William, about 1890-1900. Seuffert had emigrated from London to Auckland in 1859. Water had softened the original gelatine glue and caused extensive swelling, distortion and delamination of the marquetry and substrates. The interior had been lined with a green velvet fabric that had been stiffened with a card backing by William. ${ }^{14}$ The "scrap" card used by Seuffert was actually two lithographic prints of card tables cut from King's 1835 Sketch Book. ${ }^{15}$ Some 60 years on William considered they were obviously no longer fashionably useful.

\footnotetext{
${ }^{14}$ Cottrell Furniture of the New Zealand Colonial Era p 130. ${ }^{15}$ Cottrell Furniture of the New Zealand Colonial Era pp 367-368.
}

Anton Seuffert, undoubtedly colonial New Zealand's finest cabinetmaker, is most famous for a series of perhaps 10 or more native timber secretaires in the Louis XV style. With Grecian or English Empire aging, King's designs by 1835 onwards became more overtly eighteenth-century French revival. Seuffert based at least one caddy on King's 1829 (Grecian) cellaret while Seuffert's work table, of which two examples are known, are straight from King's 1835 (Louis XV revival) Supplementary Plates.

Scottish botanist, garden designer and author John Loudon wrote his seminal and exhaustive Encyclopaedia of Cottage, Farm and Villa Architecture and Furniture in 1833. The Encyclopaedia was so well regarded that it also continued to be re-published with seven editions until 1869.16

Loudon's bibliography conscientiously also listed over 160 titles which included those of contemporary designers such as Hope, Nicholson, Pugin, and King. When discussing British and American domestic architecture, and educating the working classes, Loudon

${ }^{16}$ Griffin "English pattern books and Australian furniture design" p 34. 
considered his "plans and views (would) extend to both hemispheres,"17 which indeed they did. Edward Jerningham Wakefield's 1848 Hand Book for New Zealand for the Use of Intending Colonists "especially recommended" Loudon's Encyclopaedia. ${ }^{18}$

Loudon's Encyclopaedia was just that; not so much a pattern book for cabinet makers as a domestic guide for settlers. Numerous copies of his Encyclopaedia arrived in Australia and the frontispiece of later editions even included Howe in Sydney, and Melville in Hobart, as publisher's agents. The Sydney Morning Herald of 16 February 1837 advertised copies for sale and the Australian Subscription Library and Mechanics Institute were lending copies by 1839 and 1842 respectively. Many prominent Australians held editions. In 1840 Lady Jane Franklyn, wife to Tasmanian Governor Sir John, sent to England for additional architectural elevations for the new

${ }^{17}$ Griffin "English pattern books and Australian furniture design" p 353.

${ }^{18}$ Wakefield, Hand Book for New Zealand p 439.

Wakefield (1820-79) was the son of New Zealand

Company director, Edward Gibbon Wakefield. He had accompanied his uncle William out on the Tory ostensibly as his secretary, became a great advocate for New Zealand colonization, member of parliament for Christchurch and Wellington Provincial Councillor.
Government House complaining that there was "not a single book in all the Island except my own London's[sic] Farm and Cottage Architecture." 19

A set of hall chairs, part of the original furnishing for Sydney's Government House which was built in 1845, are exactly modelled from Loudon's uniquely turned gothic "Parlour Chair" design. More correctly, Loudon had copied it with permission from architect and acquaintance Edward Buckton Lamb's 1830 Etchings of Gothic Ornaments. ${ }^{20}$ Lamb has been both complimented for his originality, and criticised as debasing gothic principle. In this case, the design, a "turner's throne chair," had its roots in England, or more likely Wales, between 1550 and 1650 . Lamb's depiction, dutifully copied by Loudon and finally faithfully reproduced in New South Wales, was merely a fanciful and unscholarly assemblage of aged spindles. Loudon had also, of course, unwittingly promoted the enthusiastic research and published works of another acquaintance

${ }^{19}$ Loudon Encyclopaedia title page, New Edition, 1836; Fahey, Simpson and Simpson Nineteenth Century Australian Furniture pp 215-218.

${ }^{20}$ Fahey et al Nineteenth Century Australian Furniture $\mathrm{p}$ 443, plate 351. Loudon Encyclopaedia p 1040, fig 2007.
Henry Shaw; all the while noting that "ancient (Elizabethan) fragments" from "dismantled French chateaux" were often "put together."21 Shaw's (1836) Specimens of Ancient Furniture did indeed illustrate such articles of recent invention but he did correctly show a Glastonbury chair. Two such chairs were commissioned in 1854 by the Melbourne City Council as a departing gift to Victoria's first Lieutenant-Governor Charles La Trobe. ${ }^{22}$ Even Pugin had initially struggled to accurately interpret his native gothic heritage. The more geographically-distant and historically-remote Grecian weathered a little better. Loudon's Grecian sofas and chairs ${ }^{23}$ journeyed intact to the colonies. His gothic sideboard can be found and, remarkably, the rarest of items, such as Grecian longcase clocks and a cedar music Canterbury - complete with laurel wreath. are undeniably attributable to the

${ }^{21}$ Collard Regency Furniture pp 191-192, Loudon Encyclopaedia p 1039. EB Lamb's designs for furniture in the Norman style show a marriage of old styles, some clearly architectural and a few from known objects to illustrate quaint and historically incorrect furniture concoctions. Loudon Architectural Magazine fig 166.

${ }^{22}$ Fahey and Simpson Australian Furniture p 245. Loudon does refer to Shaw's Specimens in in his 1836 revised edition, Loudon Encyclopaedia p xviii.

${ }^{23}$ Loudon Encyclopaedia pp 324, 1061; Fahey and Simpson Australian Furniture pp 294, 235. 


\section{Encyclopaedia. ${ }^{24}$}

The New Zealand experience is harder to track. Four furniture items, all in tōtara, have been attributed to cabinetmaker Samuel Johnson who was active in Nelson after 1865: a desk in Te Papa Tongarewa from an unidentified debased Louis XV pattern, a washstand, a chiffonier, now in the Nelson Provincial Museum, and a large breakfront side board, recently repatriated from New South Wales. These last three are all in the Grecian manner and the latter (sideboard) was made by Johnson from Loudon's "Pedestal Sideboard with Carvings." It is the only New Zealand object currently attributable to Loudon's Encyclopaedia. ${ }^{25}$

Several different pattern books by London cabinetmakers William Smee and Son are known but although there is agreement on the publication date of the last in 1870, there is contention regarding the earlier copies.

Possibly the earliest, Designs of Furniture by William Smee and Son, was found in South

${ }^{24}$ Loudon Encyclopaedia pp 300, 324, 349, 1070; Cornall Memories pp 193, 202, Fahey and Simpson Australian Furniture pp 294, 222.

${ }^{25}$ Loudon Encyclopaedia p 1044.
Australia and although incomplete it offers a clue. All that remains is a "Supplement" of 20 plates of designs and two additional workshop sketches of carved Regency-period scroll details, clearly drawn by a cabinetmaker. ${ }^{26}$ The designs in the favoured revivals of Grecian, gothic, Louis and Elizabethan have simple descriptions but one chaise-longue is labelled "Adelaide couch stuffed ready for covering," clearly capitalizing on the popularity of the wife of William IV. Adelaide was publicly popular throughout the marriage and when she became Queen consort in 1830 it was fashionable to use her name, most famously with the founding of the capital of South Australia in 1836. This would suggest a publication date of around the same period. The couch in discussion is a virtual copy of Thomas King's 1835 pattern which was reproduced by Loudon exact in 1842. ${ }^{27}$ Other designs from Smee relate strongly to King's illustrative style.

Smee, whose first catalogue was probably

\footnotetext{
${ }^{26}$ This is quite normal for surviving catalogues to be a random collection of plates that were privately bound long after publication.

${ }^{27}$ Loudon Encyclopaedia Supplement p 1287, fig 2323.
}

published then in $\mathrm{c} 1836,{ }^{28}$ was certainly influenced by King. Historian Frances Collard emphatically asserts, in her Regency Furniture, that King's Modern Style "was reissued several times, finally appearing as the trade catalogue of William Smee \& Son, (who was) one of the largest furniture manufacturers of the later nineteenth century." 29

That Smee's first catalogue was used by Australian cabinetmakers is well documented. Curator Robert Griffin notes that a cedar wardrobe in Elizabeth Bay House, Sydney originated from that book, while Englishmade furniture from Smee's workshops had been exported to Australia. In 1853, Robert Porter of Carthona, Darling Point advertised its contents announcing "the whole of the

${ }^{28}$ Edward Joy in the Pictorial Dictionary dated it at c1850 but most of the styles were in popular twenty years earlier, while Symonds \& Whineray's Victorian Furniture suggests a more likely c1840. The late 1830 argument is supported by historian Andrew Montana states "In line with library catalogue entries and Edward Joy's Pictorial Dictionary, which date Smee's pattern book to about

1850, an earlier publication date appeared to be revised, but it still remains likely that a first edition was published in the late 1830s." Montana "The Finsbury cabinet-makers" ftnte 32.

${ }^{29}$ Collard Regency Furniture p 29. 
furniture was expressly made to order by the justly celebrated manufacturers Messrs. Smee \& Sons, London."30

Two New Zealand-made items have been identified from Smee's first catalogue; a tōtara card table found in Nelson with columns as Grecian pylons and a rimu half-tester bed which is now in the Auckland War Memorial Museum. It once belonged to New Zealand's first governor, William Hobson. The bed seems transitional with a hint of gothic to the end posts and more obviously foliate carving so typical of French rococo. It is an exact copy from a William Smee design. He produced one catalogue in about 1840 entitled Designs for Window Curtains and Beds, ${ }^{31}$ which appears to have been the blueprint for Governor Hobson's bed. Symonds and Whineray's Victorian Furniture (1962) was formative in establishing serious analysis of nineteenthcentury design and they credit Smee's designs as $\mathrm{c} 1840 .^{32}$

${ }^{30}$ Bogle Designing Australia; Griffin "English pattern books and Australian furniture design" p 35.

${ }^{31}$ Smee Designs for Window Curtains and Beds [catalogue]

${ }^{32}$ Symonds and Whineray Victorian Furniture. Other

commentators appear to have since taken Edward Joy's assertion that 1850 is a more likely date for Smee's

Designs for Furniture with no reference to his earlier

Designs for Window Curtains and Beds. Hobson's bed
John Alfred Langford from Birmingham arrived in Wellington on the first passenger ship "Aurora" on 22nd January 1840. Later that year he was listed as a cabinetmaker, upholsterer and undertaker in Chancery Lane, Auckland. When Governor William Hobson died in September 1842, it was James Langford who "conducted the funeral." It might reasonably be suggested that he also constructed Hobson's bed from the designs of William Smee. Given the agreed date of Hobson's death in late 1842, presumably in that very bed, then it would make it the oldest known piece of colonial furniture that can be attributed to William Smee's designs.

Thomas King also died in 1842. Not only had his ideas directly transferred to his contemporary William Smee but they had traversed the globe. It is quite remarkable that, four months by sailing ship and 12,000 miles away, both King's and Smee's publications featuring the latest London fashions for Grecian, gothic, French and Elizabethan revivals were being used in New Zealand so soon after publication.

rather contradicts their "Hobson's choice." 


\section{REFERENCES}

Bogle, Michael Designing Australia: Reading in the History of Design Annandale: Pluto Press, 2002.

Bogle, Michael Designing Australia: Reading in the History of Design Annandale: Pluto Press, 2002.

Collard, Frances Regency Furniture Southbridge: Antique Collectors Club, 1985.

Cornall, Graham Memories Perth: Australian City Properties Ltd, 1990.

Cottrell, William Furniture of the New Zealand Colonial Era 1830-1900 Auckland: Reed Publishing, 2006.

Fahey, Kevin \& Andrew Simpson Australian Furniture Pictorial History and Dictionary 1788-1938 Sydney: Casuarina Press, 1998 [auction catalogue] Mitchell Library http://www.sl.nsw.gov.au/about/collections/mitchell.html

Fahey, Kevin, Andrew Simpson and Christina Simpson Nineteenth Century Australian Furniture Sydney: David Ell, 1985.

Griffin, Robert "English pattern books and Australian furniture design" Australian Antique Collector (January-June 1995) 49: 35-39.

Hope, Thomas Household Furniture and Interior Decoration London: Longman Hurst Rees Orme, 1807.

http://books.google.co.nz/books?id=Phw7AAAAcAAJ\&printsec=frontcover\&dq=The+ Modern+Style+of+Cabinet+Work+Exemplified,+in+New+Designs

Joy, Edward English Furniture 1800-1851 London: Ward Lock Ltd, 1977.

Joy, Edward Pictorial Dictionary of British 19th Century Furniture Design,

Southbridge: Antique Collectors Club, 1977.

King, Thomas Cabinet Maker's Sketchbook London: 1835.

King, Thomas Modern Style of Cabinet Work Exemplified London: T. King, 1829.

King, Thomas Specimens of Furniture in the Elizabethan and Louis Quatorze Styles London: c1840.

Lamb, Edward Buckton Etchings of Gothic Ornaments London: 1830.
Loudon, John Encyclopaedia of Cottage, Farm and Villa Architecture and Furniture London: Longman, Rees Orme Brown, Green \& Longman, 1836.

Loudon, John Encyclopaedia of Cottage, Farm and Villa Architecture and Furniture London: Longman, Rees Orme Brown, Green \& Longman, 1833.

Loudon, John Claudius Architectural Magazine London: Longman, Rees Orme Brown, Green \& Longman, 1834, v 1.

Montana, Andrew "Stylists for the Nineteenth Century: The Finsbury cabinet-makers Smee \& Sons in colonial Australia" reCollections: A Journal of Museums and Collections (April 2012) 7(1) n.p. https://recollections.nma.gov.au/issues/volume_7_number_1/papers/s tylists_for_the_nineteenth_century

Northcote-Bade, Stanley Colonial Furniture in New Zealand Auckland: A.H. \& A.W. Reed, 1971.

Shaw, Henry Specimens of Ancient Furniture London: Henry G. Bohn, 1836

Smee, William and Son Designs of Furniture London: c1837.

Smee, William Designs for Window Curtains and Beds [catalogue] London: c1840 http://ipac.nal.vam.ac.uk

Smith, George Cabinet-Maker's and Upholsterer's Guide London: Jones and Co. 1826.

Smith, Thomas Gordon, John Hall and the Grecian Style in America New York: 1996, Appendix II.

Symonds, Robert and Bruce Whineray Victorian Furniture London: Country Life Ltd, 1962.

Wakefield, Edward Hand Book for New Zealand for the Use of Intending Colonists London: John W. Parker, 1848. 